\title{
The Effect of Reflective Journal Writing on Students' Writing Ability of Narrative Text
}

\author{
Firdaus Habibi, Ismalianing Eviyuliwati, Sunardi Kartowisastro \\ Syarif Hidayatullah State Islamic University Jakarta, Jl. Ir. H. Djuanda 95, Ciputat, Indnnesia \\ Corresponding e-mail: firdaushabibi89@gmail.com
}

\begin{abstract}
This research is aimed to obtain the empirical evidence about the effect of reflective journal writing on students' writing ability of narrative text at the tenth-grade students of SMA Triguna Utama South Tangerang. The writer used quasi-experimental research which classified into a quantitative research. The population of the research was 273 students from six classes. The sample was chose by using purposive sampling technique which selected into the experimental class and the control class. It consisted of 30 students in each class. Moreover, the writer used the pretest and the post-test as the instruments of the research. In the experimental class, the writer taught the reflective journal writing by using a social media Line Application in teaching writing of the narrative text. While in the controlled class, the writer taught the students by implementing the conventional teaching technique such as asking the students to do the written exercises and answering ten reading comprehension questions based on the narrative text given. Also, the writer collected the data of this research by following some steps such as providing the pretest, providing the treatments during conducted the research, and giving the post-test at the end of the research. The data from the research were calculated by using Microsoft Excel 2017 and then would be analyzed automatically by using SPSS version 20 with the significance level 0.05. Furthermore, the result showed that the t-value of the post-test (2.071) and the gained scores (7.882) were higher than the t-table (1.667) in the significance level of 0.05 . Based on the result, if $\mathrm{t}$-value was higher than $\mathrm{t}$-table, it meant that $\mathrm{H}_{0}$ (null hypotheses) was rejected and $\mathrm{H}_{\mathrm{a}}$ was accepted. Therefore, it could be concluded that reflective journal writing was effective in improving students' writing ability of narrative text.
\end{abstract}

Keywords: reflective journal writing, writing ability, narrative text

\section{INTRODUCTION}

Learning English as a foreign language means that students should master four basics language skills which are listening, reading, speaking, and writing (Harmer, 2001: 16). As one of the language skills, writing is needed to be learned because of some considerations. Firstly, writing is being the important skill for academic purposes. Through writing, students can share their ideas and their knowledge about facts and opinions of what they have received. Secondly, writing contributes in fostering the students' critical thinking. Research conducted by Quitadamo and Kurtz has revealed that the students who are accustomed to writing regularly could gain their critical thinking performance highly (Quitadamo \& Kurtz, 2007: 149). Also, writing can be used as a tool to measure the students understanding of the materials given.

Based on the considerations above, the Ministry of Education and Culture of Indonesia has put writing into one of the basics competencies in teaching and learning process of English subject. Writing itself is learned by senior high school students through various types of text. Each of them has different objectives whether to tell the past events, or to entertain readers about imaginative stories, or to describe something. Due to the importance of writing, the tenth-grade students are encouraged to understand the narrative text. 
Moreover, it is stated in the standard competency 4.15 of 2013 Curriculum in which students should have a good understanding of the narrative text considering of social function, the structure of the texts and the language features correctly (The English Syllabus of 2013 Curriculum, 2013).

Furthermore, narrative text is aimed to entertain people about the events, legends, or imaginative stories. It is also intended to put the moral value into the stories. Nathanson added that narrative text is being the most powerful tool to grab the students attention in the teaching and learning process (Nathanson, 2006: 2). Whereas, writing is not a simple task to do even the students should write a narrative text. It can be identified by some problems that the writer faced during his teaching internship at SMA Triguna Utama.

Firstly, the tenth grade students were difficult to find the ideas of their writing. This happened because the students were not accustomed to write regularly. Consequently, this problem was similar to the research conducted by Mukti indicated that the students had limited linguistic resources, so it would be difficult for them to express the ideas in a written genre (Mukti, 2016: 2). Moreover, Saragih agreed that the difficulty of writing was caused by the students' spending much time to think about their ideas (Saragih, 2012: 3). Because of the students' difficulty to organize the ideas in writing, they needed extra times to transfer their ideas to written form. These problems also caused the difficulties in writing the narrative text. Secondly, the students had very concise time to write in the classroom. The time allotment for each English meeting was only 90 minutes in a week. In fact, the students did not only write but also did plenty of activities which engage them to participate in the classroom activities. On the other hand, some steps were needed in organizing a good writing such as choosing a topic, brainstorming, doing research, discovering the thesis statement, making an outline, writing, revising, editing and proofreading (Whitaker, 2004: 4). As a result, the students needed more time to write even to learn English

Because of the importance of writing and those problems in writing, the writer believes that the students need an appropriate technique to help them in improving their writing ability. In this research, the writer examines the reflective journal writing technique in improving the students' writing ability of narrative text.

Based on the previous research by Henter and Simona, the students' achievement can be improved, and the students' awareness of learning strategies can be raised by using reflective journal writing (Henter \& Simona, 2014: 6). Therefore, the writer agrees that the usefulness of reflective journal writing can be raised in improving the students writing ability of narrative text.

To differentiate the research to other researches, Line Application is chosen as the media to write reflective journal writing of the narrative text. The media is taken because Line Application can be an active way to have the students' respond to the teachers' input, to gain the students' awareness of the subject matter with more detail way in answering and showing the real world interaction and relevance to the questions (Gobard, 2014: 172). So far there is no one using Line Application as a media in writing reflective journal even to help students in fostering their writing ability of narrative text.

Finally, based on the reason above, the writer would like to conduct research about The Effect of Reflective Journal Writing on Students' Writing Ability of Narrative Text.

Writing skill is necessary to be learned in learning English beside speaking. Although both of them are classified into the productive skills, writing is contrast different from speaking. In speaking, the speakers use their voice such as pitch, stress, and rhythm to convey their ideas. Also, the gestures and facial expression are needed to express the information clearly. Whereas, In writing, the writer has to rely on the words on the page to express their meaning (Raimes, 1983: 4).

A writer also should consider some aspects in writing. For instances, knowing the purpose of writing whether to explain something, amuse the readers about the stories, telling the past events or others. So, the readers will be easier to understand the information that is conveyed. On the other hand, the writers should have a good understanding of the content of writing such as the relevance to the topic discussed, clarity, originality, logic and so on. It is committed to keeping the writing on the track based on the topic, and the reader will not be confused about the information.

Reflective journal writing requires the students to map of the students' progress and changes in their thinking about a subject or a topic or about the learning journey in which the students are engaged in. Also, a reflective journal writing can be used as one of the techniques to assess the students' understanding of the learning materials given. It allows the students to think critically through different cognitive processes such as prediction, brainstorming, reflection and questioning (Rawahi \& 
Balushi, 2015: 367-379). Also, the reflective journal writing encourages students to express their ideas and thinking about the world around them. Reflective journal writing can be referred to "written documents that students create as they think about various concepts, events, or interactions over the period to gain insights into self-awareness and learning" (Mansor, 2011: 507).

Additionally, the students would be asked to write in regular entries that given by the teacher who would then have to be submitted and assessed using the rubric of narrative text writing. The students should answer the questions from the journal entries. In this research, the reflective journal writing is used to examine the students' understanding of narrative text given to improve their writing ability. The teacher who assigns the students' reflective journal writing often see an increase in participation from their students, and participating in the classroom activities and discussions. Also, the teacher can know the concepts that students understand based on the text given and which concept should be revised. It can be concluded that reflective journal writing can be one of the useful technique to improve the students' writing ability.

\section{METHODS}

\subsection{Research Design}

This research was classified as a quantitative research. Comparing to another type of research, it emphasized the researchers to use a statistical procedure that provided the information discussed in the research questions or hypotheses (Creswell, 2012: 15). The writer examined two variables. They were reflective journal writing as the independent variable and the students' writing ability of narrative text as the dependent variable.

Specifically, a quasi-experimental design was used in the research. This research design required to select the students who would represent the population of the research. Then, after selecting the students, they would be assigned to the experimental class and controlled class. The writer considered to choose the students in both experimental class and controlled class based on the students' scores while learning English in SMA Triguna Utama.

\subsection{Population and Sample}

The population of this research was the whole students of SMA Triguna Utama on the second semester of academic year 2016/2017. Each of grade divided into two classes from XA, XB, XI IPA, XI IPS, XII IPA and XII IPS. Therefore, there were 273 (two hundred and seventy-three) students altogether who had been become the population of this research. To choose the sample of the research, the writer used purposive sampling technique which selected the students into experimental class and controlled class. Based on the English test result, most of the students of 10B got lower scores rather than those of 10A. Consequently, class 10B, consisting of 30 students, was chosen to be the experimental class and class 10A, consisting of 30 students, was chosen to be the controlled class.

\subsection{Research Instrument}

The process of collecting the data involved a written test as the instrument of the research. In this research, the writer used pre-test and post-test as the written test. The pre-test was intended to know the students' writing ability before the treatment given. On the other hand, the post-test was given to measure whether the reflective journal writing had a significant effect toward the students' writing ability of narrative text.

Also, the topics between pre-test and post-test were different. For the pre-test, the students were instructed to read a passage entitled Issumboshi for about thirty minutes. Then, after reading the passages, they were allowed to write reflective journal writing based on the guided questions. To examine the students' writing ability of narrative test after the treatments, the writer chose a passage entitled The Legend of Malin Kundang for the posttest. Therefore, the procedure in writing the reflective journal was similar to the pre-test procedure. The reflective journal also should follow the writing guideline and answer the questions stated.

My Reflective Journal Writing
Name :
Class :
After reading the passage (based on the title during
he test), please kindly to write the reflective journal
pased on these questions given.
1. During the hands-on-story entitled (based on
the title), what information did you observe?
2. Which part did you like from the story Why
did you like that part?
3. Which part did you dislike based on the story?
Why did you dislike that part?
5. What have you learned from the story?


The writer also provided the specific scoring to assess the students' writing performance. Regarding the use of scoring, it would serve the strengths and the weaknesses of the students in writing the reflective journal. In this research, the scoring of the writing was adapted from PARCC (Partnership for Assessment of Readiness of Collage and Careers) which specifically assessed the students' writing ability of narrative text (www.parcconline.com, 2017). There were four criteria showed to analyzed the students' writing ability of narrative text such as the development of ideas, organization, clarity of language and knowledge of language and conventions.

\subsection{Technique of Data Collection}

The writer collected the data by giving pre-test, giving different treatments in experimental class and controlled class and giving post-test for investigating the effect of reflective journal writing on students' writing ability of narrative text. Meanwhile, giving different treatment was useful activity to obtain the significant result between experimental class and controlled class.

During the treatment, the writer asked the students in the experimental class to write reflective journal writing based on the guided questions. After they wrote the reflective journal writing, they should submit their assignments on Line Application. Whereas, the students in the controlled class were asked to do written exercises and answered the questions based on the narrative text given. At the end of the research, the writer gave post-test to examine the result whether the reflective journal writing showed the significant effect on students' writing ability of narrative text or not.

\section{RESULT AND DISCUSSION}

Based on the data on the pretest, it can be identified that the maximum score of the experimental class is 75 and the maximum score of controlled class is 80 . In addition, the minimum score in the experimental class and the controlled class are 5. Furthermore, the data reveals that $90 \%$ students get low scores in the experimental class and $53 \%$ students get low scores in the controlled class. It means that most of the students in the two classes still had less knowledge about how to write reflective journal writing and less understanding of the narrative text. There were some students who got score $60-70.6 .67 \%$ students in the experimental class and $20 \%$ of students who got average scores in the controlled class. Those students had standard knowledge and understanding of writing the reflective journal, but their writing skill still needs to be improved. Then, only a few of students got high scores between 71 to 80 in writing the reflective journal. It was represented by one student from the experimental class and eight students in the controlled class. Therefore, there must be an effort to improve the students' ability in writing the reflective journal of narrative text.

Furthermore, there were no students who achieve the score more than 75 in the experimental class and score 80 in the controlled class. Based on the data, the mean score of the experimental class was 32.67, and the mean score of the controlled class was 50.67. As a result, the mean scores indicate that the experimental class obtained lower mean score than the controlled class.

The data show that $\mathrm{t}(58)=-3.248, \mathrm{p}=0.002$ or $\mathrm{t}-$ value $(-3.248)<\mathrm{t}$-table $(1.667)$ proved no significant difference between the experimental class $(\mathrm{M}=32.67$ $\mathrm{SD}=18.557)$ and the controlled class $(\mathrm{M}=50.67 \mathrm{SD}=$ 24.023). Therefore, the students in the two classes had same ability before the treatment

After conducting the treatments for about four times, the writer carried out the posttest. Based on the data, the maximum score in the experimental class is 85 , and the maximum score in the controlled class is 80 . On the other hand, the minimum scores between the experimental class and the controlled class indicate a number which is not too different. The experimental class gets 10 for the minimum score, and the controlled class get 5 for the minimum score. Furthermore, the data shows $36 \%$ of the students got low scores in the experimental while $50 \%$ of the students in controlled. It reveals that the students' writing ability reflective journal of narrative text has been improved after giving the treatments. There are still many students in the controlled class could not gain their scores because there is no a specific guidance to write the reflective journal.

Moreover, the avarage scores, between 60 to 70 , were achieved by 15 students in the controlled class and there were no students get more than 70 in the controlled class. it happened because the students were not asked to write the reflective journal writing of the narrative text. It is different to the students in the experimental class. Because the students were given many treatments to write the reflective journal, so their writing ability could be achieved. It can be seen that $36.67 \%$ of the students gain the avarage score in the experimental class while $50 \%$ 
of the students gain the avarage score in the controlled class. Also, the table above clarify that there is no students in the controlled class who can get the score above 80 . On the other hand, the difference mean scores between the experimental score (60) and the controlled class (50.33) were not too different. Thus, it can be concluded that the students' writing ability in the experimental class was improved which the mean score of post-test (60) shows higher than the pre-test (32.67).

After the treatments during the research, the writer also examined the t-test. The t-test of post-test shows that $\mathrm{t}(58)=2.071, \mathrm{p}=0.043$. It indicated that there was a significant different results between the experimental class $(\mathrm{M}=60, \mathrm{SD}=15.143)$ and the controlled class $(\mathrm{M}=50.33, \mathrm{SD}=20.592)$.

Table 1. The T-Test Result of Post-test Scores

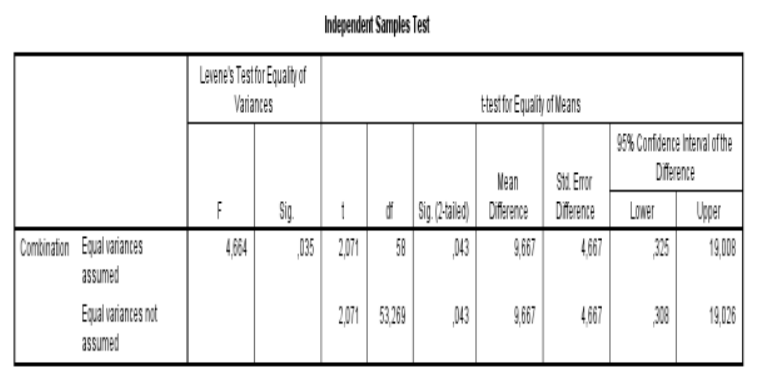

The table above shows the information about tvalue which is 2.071 with the Sig. (2-tailed) 0.043 . Then, the t-value is compared to the t-table to know whether the reflective journal writing is effective to improve the students' writing ability of narrative text or not. The t-table is taken from the requirement which has been the standard in analyzing the data. The t-table shows 1.667 with 70 as the degree of freedom (df) in the significance level 0.05 or 0.95 . The comparison shows that t-value (2.071) > t-table (1.667) and the Sig (2-tailed) is $0.043<0.05$. It means that the reflective journal writing is effective to improve the students' writing ability of narrative text.

\section{CONCLUSIONS}

This research was conducted in a quasi-experimental study with the purposes to know whether or not reflective journal writing is effective in improving students' writing of narrative at the tenth grade students of SMA Triguna Utama on the data description, statistical calculation, and hypotheses testing, explained in the chapter four, it was found that the t-value in both post-test (2.071) and gained scores (7.882) are higher than the t-table (1.667) in the significance level of 0.05 . Thus, $t$-test result $>\mathrm{t}$ table which means that the $\mathrm{H}_{0}$ (null hypothesis) is rejected and $\mathrm{H}_{\mathrm{a}}$ (alternative hypothesis) is accepted. In other words, reflective journal writing is effective in improving students ' writing ability of narrative text.

\section{ACKNOWLEDGEMENTS}

The authors wish to thank Faculty of Education Sciences UIN Syarif Hidayatullah Jakarta.

\section{REFERENCES}

Creswell, J. W.(2012). Educational Research Planning, Conducting and Evaluating Quantitative Research Fourth Edition. United States of America: Pearson Education Inc, 15.

Gobard, W. G., Van De. (2014). Evaluating Digital Literacy Skills of EFL Thai Students' Using Line Chat Application. Executive Journal, 172.

Harmer, J. H. (2001). The Practice of English Language Teaching Third Edition. New York: Longman Publishing.

Henter, R., Simona, E. (2014). Reflective Journal Writing as a Metacognitive Skill. International Conference of Scientific Paper AFASES 2014 Brasov Romania.

Mansor, A. Z. (2011). Reflective Learning Journal Using Blog. Procedia Social and Behaviour Sciences, 18, 507.

Mukti, A. (2016). The Effectiveness of Dialogue Journals in Improving the Skill in Writing Narrative Text, International Journal of English Education (IJEE), $3(1), 2$.

Nathanson, S. (2006). Harnessing the Power of Story : Using Narrative Reading and Writing Across Content Area. Reading Horizons, 47(1), 2.

Quitadamo, I. J., Martha J. K. (2007). Learning to Improve: Using Writing to Increase Critical Thinking Performance in General Education Biology. CBE Life Science Education, 6, 149.

Rawahi, N. M., Balushi, S. M. (2015). The Effect of Reflective Science Journal Writing on Students' Self-Regulated Learning Strategies. International. Journal of Environment and Science Education, 10(3), 367-379.

Saragih, Z. S. (2012). Improving Students' Achievement in Writing Narrative text through Think-Pair-Shair Technique. Journal of English Language Teaching and Learning of FBS UNIMED, 1(1), 3.

Whitaker, A. (2009). Academic Writing Guide: A Step-byStep Guide to Writing Academic Papers. Slovakia: City University of Seattle. 